\title{
Studi In Silico Senyawa Tanaman Nerium oleander terhadap STAT-3 pada Kanker Payudara
}

\author{
Anita Dewi Permatasari Komarudin ${ }^{1}$, Muhammad Fadhil Ghassani Purnama ${ }^{1}$, Alma Yunita Sari ${ }^{1}$, \\ Afifah Izzati ${ }^{1}$, Elma Nadhifa Mahmada Rizka Sahila ${ }^{1}$, Syahrul Hidayat ${ }^{1}$, Tantie Noer Apriliya $1^{1}$ dan \\ Muchtaridi $^{1}$ \\ ${ }^{1}$ Departemen Analisis Farmasi dan Kimia Medisinal, Fakultas Farmasi, Universitas Padjadjaran, Jatinangor - Jl. Raya Bandung - \\ Sumedang KM. 21. Jawa Barat. Indonesia, 45363
}

Reception date of the manuscript: 2 Juli 2021

Acceptance date of the manuscript: 14 Agustus 2021

Publication date: 31 Desember 2021

\begin{abstract}
Breast cancer is a type of malignant tumor that develops in the breast due to the cell's abnormal growth. One of the chemotherapy agents used is paclitaxel, but its use causes various side effects. Therefore, the search for other compounds that can be used as an alternative treatment with minimal side effects is carried out. The compounds of oleandrin, oleandrigenin, and odoroside A derived from the leaves of the Nerium oleander have the potential to inhibit phosphorylation activation through a pathway mediated by phospho-STAT-3. The purpose of this study was to determine the best compound through molecular and pharmacokinetic interactions of the compounds found in Nerium oleander. Interaction studies are carried out by monitoring the aspects of in silico molecular docking simulation, predictions of absorption, distribution, metabolism and toxicity through the PreADMET web were also carried out, and Lipinski's rules. Oleandrin compounds have good pharmacokinetic activity with HIA and Caco2 absorption values of $94.293 \%$ and $25.490 \mathrm{~nm} / \mathrm{s}$, PPB and BBB values of $82.203 \%$ and $0.046 \%$. Oleandrin has a binding energy of $-7.22 \mathrm{kcal} / \mathrm{mol}$ with an inhibition constant of $5.07 \mu \mathrm{M}$. Oleandrin does not have mutagenic potential but does have carcinogenic potential. Oleandrin has no mutagenic potential but has carcinogenic potential. However, in vitro studies have shown that oleandrin has the ability to inhibit tumor cell proliferation and stimulate tumor cell apoptosis.
\end{abstract}

Keywords-breast cancer, molecular docking, oleandrin, STAT-3

\begin{abstract}
Abstrak - Kanker payudara merupakan suatu jenis tumor ganas yang berkembang pada sel-sel payudara yang tumbuh secara abnormal. Salah satu agen kemoterapi yang digunakan adalah paclitaxel, namun penggunaannya menimbulkan berbagai efek samping. Maka dari itu, dilakukan pencarian senyawa lain yang dapat digunakan sebagai alternatif pengobatan dengan efek samping seminimal mungkin. Senyawa oleandrin, oleandrigenin, dan odorosida A yang berasal dari daun tanaman Nerium oleander memiliki potensi menghambat aktivasi fosforilasi melalui jalur yang dimediasi oleh fosfo-STAT-3. Tujuan dari studi ini adalah untuk menentukan senyawa terbaik melalui interaksi molekular dan farmakokinetik senyawa tanaman Nerium oleander. Studi interaksi dilakukan dengan metode penambatan molekuler secara in silico. Selain itu dilakukan juga prediksi absorpsi, distribusi, metabolisme dan toksisitas melalui web PreADMET, serta kesesuaian aturan Lipinski. Senyawa oleandrin memiliki aktivitas farmakokinetik yang baik dengan nilai absorpsi HIA dan Caco2 sebesar 94,293\% dan $25,490 \mathrm{~nm} / \mathrm{s}$, nilai PPB dan BBB sebesar 82,203\% dan 0,046\%. Oleandrin memiliki energi ikat sebesar -7,22 kkal/mol dengan konstanta inhibisi sebesar 5,07 $\mu \mathrm{M}$. Oleandrin tidak memiliki potensi mutagenik tetapi memiliki potensi karsinogenik. Namun, sudah terdapat penelitian secara in vitroyang membuktikan bahwa oleandrin memiliki kemampuan untuk menghambat proliferasi sel tumor dan menstimulasi apoptosis sel tumor.
\end{abstract}

Kata Kunci-kanker payudara, penambatan molekuler, oleandrin, STAT-3

\section{Pendahuluan}

Kanker merupakan penyakit paling umum kedua penyebab kematian setelah penyakit jantung. Global Burden of Cancer (GLOBOCAN) menyebutkan bahwa kanker yang paling sering didiagnosis di seluruh dunia adalah kanker paru-

Penulis koresponden: Anita Dewi Permatasari Komarudin, E-mail: anita19004@mail.unpad.ac.id paru $(13 \%)$, kanker payudara $(11,9 \%)$, dan kanker kolorektal $(9,7 \%)$. Kanker paru-paru merupakan kanker dengan angka kematian tertinggi $(19,4 \%)$, diikuti kanker kolorektal $(9,4 \%)$, dan kanker hati $(8,3 \%)$, sedangkan kematian akibat kanker payudara $(6,9 \%)$ menduduki peringkat ke-5 setelah kanker perut $(7,7 \%)$. The North American Association of Central Cancer Registries (NAACCR) memperkirakan hampir 1,9 juta kasus kanker baru akan terjadi di tahun 2021 dengan kasus baru kanker payudara sebanyak 284.200 
dan kasus kematian akibat kanker payudara sebanyak 44.130 kasus (Siegel et al., 2021). Kanker memiliki karakter pertumbuhan dan penyebaran sel yang abnormal sehingga dapat menyebabkan kematian apabila tidak ditangani. Proses paling penting dari pertumbuhan dan penyebaran sel adalah proses transkripsi dan kemampuan apoptosis. Salah satu jalur yang dapat menginisiasi transkripsi dan berhubungan dengan kemampuan apoptosis pada kanker payudara adalah jalur yang melibatkan protein Signal Transducer and Activator of Transcription-3 (STAT-3) (Liu et al., 2020).

STAT-3 memiliki peran pada regulasi proliferasi sel kanker payudara. Fosforilasi STAT-3 menyebabkan peningkatan proliferasi sel dan penurunan apoptosis sel (Mas'ula dkk., 2018). STAT-3 adalah penanda diagnostik tumor awal dan diketahui dapat meningkatkan keganasan kanker payudara. Pada sel kanker, protein STAT-3 ini mengalami ekspresi berlebih. Data klinis dan praklinis terbaru menunjukkan keterlibatan STAT-3 yang diekspresikan secara berlebihan dan diaktifkan secara konstitutif dalam perkembangan, proliferasi, metastasis, dan kemoresistensi kanker payudara (Ma et al., 2020).

Salah satu pengobatan kanker payudara adalah kemoterapi dengan regimen FAC (5-fluorourasil, doksorubisin, siklofosfamid) sebagai lini pertama, regimen CMF (siklofosfamid, metotreksat, 5-fluorourasil), trastuzumab, regimen AT (doksorubisin, paclitaxel), FEC (5-fluorourasil, epirubicin, siklofosfamid), atau kombinasi paclitaxel dan docetaxel. Namun, kemoterapi dapat menimbulkan berbagai efek samping (Darmawan dkk., 2019; Sukandar dkk., 2014). Salah satu obat yang digunakan dalam kemoterapi adalah paclitaxel. Paclitaxel dapat digunakan sebagai agen terapi tunggal atau dikombinasikan dengan agen kemoterapi lain. Paclitaxel biasanya digunakan sebagai kombinasi kemoterapi dengan cisplatin, doksorubisin, atau siklofosfamid (Ashariati, 2019). Namun, terdapat efek samping dalam penggunaan obat-obatan ini seperti perubahan warna kuku, warna urin menjadi merah, rambut rontok, alergi, nyeri, mual, ekstravasasi, kesemutan, leukopenia, nafsu makan menurun, dan depresi sumsum tulang (Darmawan dkk., 2019).

Akibatnya, suatu terobosan pengobatan kanker payudara dengan efektifitas tinggi dan efek samping yang minimal diperlukan. Salah satu upaya pengobatan kanker payudara adalah dengan menghambat aktivitas STAT-3. STAT-3 merupakan salah satu dari 7 anggota STAT family yang tersusun dari 770 asam amino. STAT-3 merupakan faktor transkripsi yang diaktivasi oleh Gp130 yang merupakan hasil respon terhadap IL-6. Protein STAT-3 memiliki 5 domain yaitu N-terminal, 4helix bundle, -barrel connector, $\mathrm{SH} 2$ domain, dan C-terminal domain (Wongkar et al., 2019). Protein STAT-3 memiliki sisi aktif yaitu Lys591, Arg609, Ser611, Ser613 sebagai residu asam amino ikatan kunci (Sgrignani et al., 2018) dan Lys140, Tyr705 sebagai residu asam amino katalitik (Liu et al., 2014).

Beberapa senyawa polifenol seperti oleandrin, oleandrigenin, dan odorosida A menunjukkan adanya penghambatan invasi melalui jalur yang dimediasi fosfo-STAT-3 yang terlibat dalam regulasi molekul yang berhubungan dengan invasi (Ko et al., 2018). Ketiga senyawa tersebut ditemukan pada daun tanaman Nerium oleander. Melalui penelitian yang dilakukan secara in vitro, senyawa oleandrin yang merupakan senyawa utama dari tanaman N. oleander diketahui memiliki aktivitas antikanker terhadap beberapa jenis kanker, seperti me- lanoma, kanker prostat, kanker paru-paru, leukemia, kanker payudara, kanker pankreas, sarkoma, dan kanker otak (Ko et al., 2018; Kanwal et al., 2020; Kumar et al., 2013). Pada uji in vitro, senyawa oleandrin dan odorosida A diujikan pada sel kanker payudara MDA-MB-231 dan radio-resistant (RT-R) MDA-MB-231. Didapatkan hasil bahwa senyawa oleandrin pada IC50 $50 \mathrm{nM}$ dan odorosida A pada IC50 $100 \mathrm{nM}$ menginduksi perubahan morfologi pada sel MDA-MB-231 dan sel RT-R-MDA-MB-231 dengan cara yang bergantung pada waktu (24, 48, dan 72 jam). Perubahan morfologi ini berupa penyusutan sel, blebbing, dan disorganisasi sel pada waktu 48 dan 72 jam. Selain itu, kedua senyawa secara signifikan diketahui dapat menurunkan pembentukan koloni sel kanker (Ko et al., 2018).

Senyawa oleandrin dan oleandrigenin diketahui mampu menghambat proliferasi sel tumor dan menstimulasi apoptosis sel tumor tersebut sebagai hasil dari tingginya $\mathrm{Ca}++$ intraseluler. Selain itu, kedua senyawa ini juga diketahui dapat menghambat ekskresi fibroblast growth factor-2 (FGF-2) melalui interaksi membran dan penghambatan pompa Na, KATPase (Kumar et al., 2013).

Ketiga senyawa tersebut memiliki aktivitas yang sama seperti obat yang telah dipakai untuk kanker payudara, yakni paclitaxel. Paclitaxel juga bekerja menginhibisi STAT-3 dengan menurunkan fungsi STAT-3 fosforilasi pada kanker payudara (Walker et al., 2011). Untuk mengetahui interaksi antara ketiga senyawa tersebut terhadap residu asam amino yang terdapat pada STAT-3 secara lebih rinci melalui komputasi, simulasi penambatan molekuler perlu dilakukan untuk memprediksi adanya interaksi tersebut.

\section{BAHAN DAN METOde \\ Bahan}

Bahan-bahan yang digunakan dalam penelitian ini adalah struktur PDB STAT-3 yang digunakan diperoleh dari RCSB Protein Data Bank (PDB) (https://www.rcsb.org/search) dengan PDB ID 6NJS dan senyawa-senyawa bioaktif dari daun tanaman Nerium oleander yaitu oleandrin, oleandrigenin, dan odorosida A serta obat pembanding yaitu paclitaxel.

\section{Alat}

Perangkat keras yang digunakan dalam penelitian ini berupa komputer pribadi dengan merk Hewlett-Packard® dengan prosesor Intel® Core TM i5-7200U CPU, CPU $2.50 \mathrm{GHz}$, dan 8 GB RAM. Program yang digunakan dalam penelitian ini adalah The ChemPro 12.0 dan ChemDraw Ultra 12.0 untuk menggambar struktur 2D dan mengekspresikan struktur ligan 3D. Program AutoDockTools 4.2.6 (The Scripps Research Institute, USA) untuk melakukan simulasi docking molekuler. Program The BIOVIA Discovery Studio 2020 Client untuk memvisualisasikan struktur 3D.

\section{Metode}

\section{Akuisisi Struktur}

Struktur PDB STAT-3 yang digunakan diperoleh dari RCSB Protein Data Bank (PDB) (https://www.rcsb.org/) dengan PDB ID 6NJS. Protein dipreparasi menggunakan BIOVIA Discovery Studio dan untuk ligan dipreparasi menggunakan aplikasi ChemDraw dan Chem3D. Struktur 2D digambar pada program ChemDraw dan diminimisasi energinya ke bentuk 3D menggunakan program Chem3D Pro 
12.0 .

\section{Simulasi Penambatan Molekuler}

Senyawa Ekstrak Etanol Daun Kenikir dan Senyawa Standar Simulasi penambatan molekuler dilakukan dengan $\mathrm{Au}-$ todock 4.2.6 dengan didahului modifikasi struktur ligan dan protein yang disimpan dengan format PDBQT. Lalu dilakukan simulasi penambatan molekuler dengan penetapan ukuran grid box 28 x 56 x 34 dengan koordinat x = 13,498; $\mathrm{y}=54,118$; dan $\mathrm{z}=0,1$ pada jarak $0,375 \AA$. Kemudian, dilakukan implementasi hasil dengan 100 GA Lamarckian dengan ukuran populasi 150 docking. Luaran dari simulasi penambatan molekuler berupa clustering histogram, RMSD, perkiraan energi bebas pengikatan, serta perkiraan konstanta penghambat. Konformasi kompleks hasil simulasi penambatan molekuler, interaksi ligan, dan diagram 2D dapat dilihat melalui perangkat lunak BIOVIA Discovery Studio.

Prediksi Absorpsi, Distribusi, Metabolisme, dan Toksisitas

Prediksi absorpsi, distribusi metabolisme, dan toksisitas senyawa uji dan obat pembanding dilakukan dengan cara menggambarkan struktur senyawa pada web PreADMET (https://preadmet.bmdrc.kr/) dan akan didapatkan hasil dari setiap aspek. Parameter yang diperhatikan meliputi nilai HIA dan Caco2 pada profil absorpsi, nilai PPB dan BBB pada profil distribusi, aktivitas CYP2C19, CYP2C9, CYP2D6, CYP3A4 pada profil metabolisme, serta potensi mutagenik dan karsinogenik pada profil toksisitas.

\section{Prediksi Kesesuaian Senyawa melalui Aturan Lipinski}

Prediksi kesesuaian senyawa melalui aturan Lipinski dilakukan dengan cara menggambarkan struktur atau memasukkan format SMILES senyawa pada web SwissADME (http://www.swissadme.ch/). Berdasarkan aturan Lipinski, senyawa yang dapat digunakan sebagai kandidat senyawa aktif dan dapat diberikan secara oral harus memenuhi kriteria berupa berat molekul $\leq 500$, nilai $\log \mathrm{P} \leq 5$, ikatan hidrogen donor $\leq 5$, dan ikatan hidrogen akseptor $\leq 10$.

\section{HASIL}

\section{Visualisasi Farmakofor Ligan}

Farmakofor merupakan fitur penting atau substruktur kimia yang berkorespondensi dengan aktivitas biologi. Dengan menggunakan program LigandScout, dapat dilihat bahwa seluruh senyawa uji dan obat pembanding memiliki gugus farmakofor sehingga memiliki potensi terhadap aktivitas biologi.

\section{Simulasi Penambatan Molekuler}

Senyawa Ekstrak Etanol Daun Kenikir dan Senyawa Standar Simulasi penambatan molekuler diawali dengan validasi metode menggunakan cara penambatan ulang terhadap ligan alami ([(2-[(5S,8S,10aR)-3-acetyl-8- $((2 \mathrm{~S})-$ 5-amino-1 [(diphenylmethyl)amino]-1,5-dioxopentan-2ylcarbamoyl)-6-oxodecahydropyrrolo[1,2-a][1,5]diazocin5-yl]carbamoyl-1H-indol-5-yl)(difluoro)methyl]phosphonic acid) dengan reseptor asal (6NJS) yang menghasilkan RMSD sebesar 1,429 A. Hasil simulasi penambatan molekuler antara paclitaxel dengan senyawa uji oleandrin, odorosida $\mathrm{A}$, dan oleandrigenin berupa energi ikat $(\Delta \mathrm{G})$, konstanta inhibisi (Ki), dan interaksi asam amino. Melalui

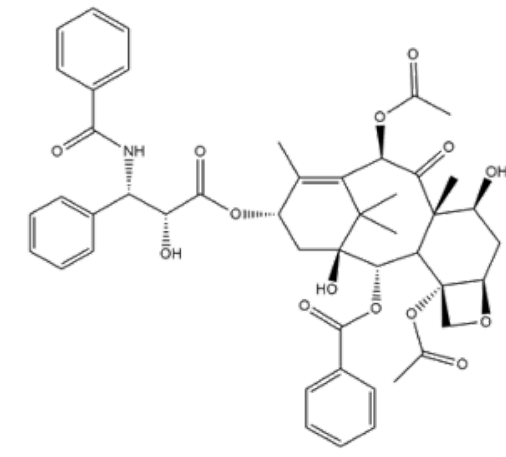

Gambar. 1: Struktur Paclitaxel

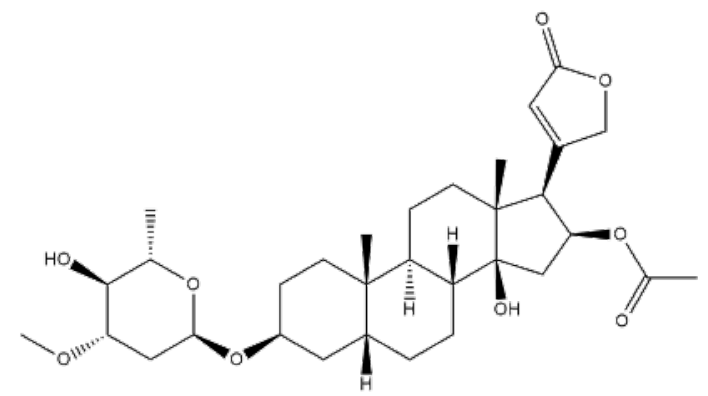

Gambar. 2: Struktur Oleandrin

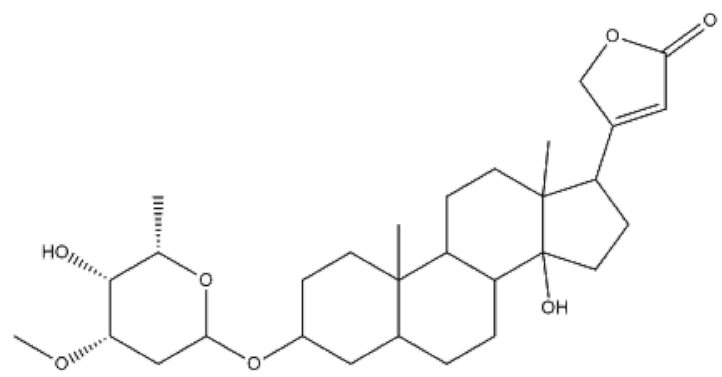

Gambar. 3: Struktur Odorosida A

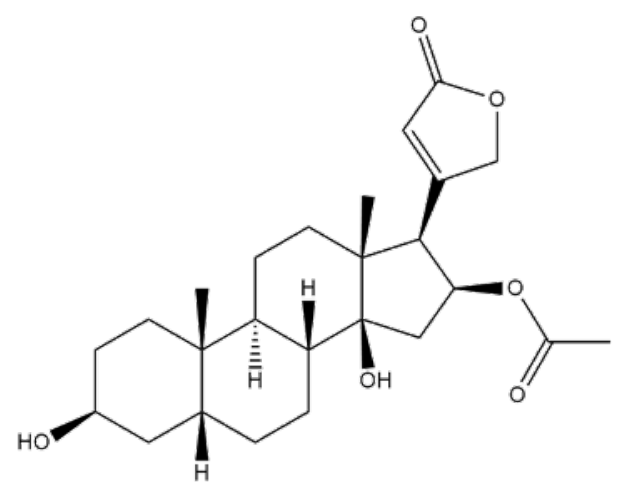

Gambar. 4: Struktur Oleandrigenin

hasil ini dapat ditentukan senyawa dengan interaksi terbaik, yakni oleandrin (Tabel 1).

Prediksi Absorpsi, Distribusi, Metabolisme, dan Toksisitas

Profil absorpsi, distribusi, metabolisme, dan toksisitas dari ligan yang dianalisis yang terdiri dari absorbsi dilihat dari 
nilai HIA dan Caco2 dan distribusi dilihat dari nilai PPB dan BBB. Kemudian, uji toksisitas yang terdiri dari uji mutagenik dan karsinogenik. Nilai hasil prediksi absorpsi, distribusi, metabolisme, dan toksisitas senyawa oleandrin berturut turut adalah $94,293 \%, 25,49 \%, 82,203 \%$, dan 0,046\% (Tabel 2).

\section{Aturan Lipinski}

Hasil prediksi aturan Lipinski ini dapat membantu untuk melihat tingkat absorpsi atau permeabilitas suatu obat terhadap lipid bilayer yang terdapat di tubuh manusia (Tabel 3).

\section{Pembahasan}

Kanker payudara merupakan sejumlah sel yang tumbuh dan berkembang dengan tidak terkendali pada kelenjar, saluran kelenjar, dan jaringan yang menunjang payudara. Kanker payudara ini dapat ditangani dengan menggunakan agen kemoterapi salah satunya yaitu paclitaxel. Pada simulasi penambatan molekuler ini pun digunakan paclitaxel sebagai obat pembanding. Paclitaxel ini biasa digunakan untuk mengobati kanker ovarium, payudara, paru-paru, pankreas, dan kanker lainnya. dengan dosis obat paclitaxel adalah 175 $\mathrm{mg} / \mathrm{m} 2$ secara intravena melalui infus yang habis dalam 3 jam dan diberikan satu kali setiap 3 minggu (PIONAS, 2021). Mekanisme kerja dari paclitaxel ini adalah mengikat mikrotubulus untuk mencegah pembelahan sel kanker dan menginduksi kematian sel kanker. Obat ini memiliki beberapa efek samping yaitu, sepsis, mual, muntah, dan diare. Gangguan konduksi, gagal jantung kongestif, dan disfungsi ventrikel kiri jarang terjadi, namun dapat berakibat fatal (MIMS, 2021). Gejala yang sering dikeluhkan saat menjalani terapi adalah lemas, rasa lelah, meningkatnya suhu tubuh, dan berkurangnya kontrol terhadap otot. Bahkan dapat terjadi komplikasi pada lokasi penyuntikan yaitu berupa nyeri, eritema, edema, dan indurasi. Oleh karena itu untuk mengurangi resiko dari penggunaan obat paclitaxel, dilakukan pencarian senyawa lain yang dapat digunakan sebagai bahan alternatif untuk pengobatan kanker payudara dengan efek samping seminimal mungkin.

Oleandrin terbukti dapat menurunkan viabilitas sel kanker highly metastatic MDA-MB-231 dan radio-resistant (RT-R) MDA-MB-231 (Ko et al., 2018), sehingga memiliki potensi untuk mengurangi keterbatasan pengobatan kanker payudara saat ini yang mengarah pada resistensi dan kekambuhan penyakit. Simulasi penambatan molekuler dilakukan untuk memprediksi lebih lanjut interaksi oleandrin terhadap senyawa asam amino kunci pada STAT-3, yaitu Lys591, Arg609, Ser611, dan Ser613 (Sgrignani et al., 2018) dengan parameter nilai Root Mean Square Deviation (RMSD). Hasil penambatan molekul dinyatakan valid jika memiliki nilai RMSD $<2 \AA$ (Muttaqin dkk., 2019).

Penambatan molekuler dilakukan untuk memprediksi posisi dan orientasi ligan saat terikat dengan protein berdasarkan interaksi antara ligan dan protein (Arwansyah dkk., 2014). Sebelum dilakukan simulasi penambatan molekuler, dilakukan validasi dengan menambatkan ulang ligan bawaan dengan protein STAT-3 menggunakan program AutoDock. Validasi ini ditujukan untuk memastikan metode yang digunakan baik dan dapat digunakan untuk tahap penelitian selanjutnya. Parameter yang digunakan yaitu nilai Root Mean Square Deviation (RMSD). RMSD merupakan pengukuran dua pose dari perbandingan posisi atom antara struktur eksperimental dengan struktur yang ditambatkan pada protein
(Lestari dkk., 2015). Metode dikatakan valid apabila diperoleh nilai $\leq 2 \AA$ (Muttaqin dkk., 2019). Hasil penambatan ulang ligan alami menunjukkan nilai RMSD sebesar 1,429 yang menunjukkan bahwa metode ini valid dan dapat digunakan pada penambatan molekuler dengan senyawa uji.

Setelah dilakukan simulasi penambatan molekuler dengan senyawa uji, didapatkan nilai energi ikat $(\Delta \mathrm{G})$ dan konstanta inhibisi (Ki) yang menunjukan afinitas antara ligan uji dengan protein. Ikatan yang terbentuk akan semakin stabil apabila semakin kecil nilai ikatan yang diperoleh, seperti yang tertera pada rumus $\mathrm{G}=-\mathrm{RT} \ln \mathrm{Ki}($ Laksmiani et al., 2016). Dari ketiga senyawa uji, diperoleh senyawa terbaik yakni senyawa oleandrin dengan nilai energi ikat sebesar -7,22 kkal/mol dan konstanta inhibisi sebesar 5,07 $\mu \mathrm{M}$. Sementara itu, nilai energi ikat dan konstanta inhibisi untuk paclitaxel sebagai obat pembandingnya yakni $-7,38 \mathrm{kkal} / \mathrm{mol}$ dan $3,89 \mu \mathrm{M}$.

Dalam menentukan senyawa obat yang baik juga perlu dilakukan peninjauan dari aspek PreADMET yang meliputi aspek absorpsi (HIA dan Caco2), distribusi (PPB dan BBB), metabolisme (CYP2C19, CYP2C9, CYP2D6, dan CYP3A4), dan toksisitas (potensi mutagenik dan karsinogenik). Simulasi PreADMET yang telah dilakukan menunjukkan bahwa senyawa oleandrin memiliki hasil yang baik. Aspek tinjauan pertama adalah aspek absorpsi yang meliputi nilai Human Intestinal Absorption (HIA) dan Caco2. Senyawa oleandrin memiliki nilai HIA sebesar 94,293\%. Nilai tersebut merupakan nilai yang baik dan memenuhi standar karena nilai HIA yang berada pada rentang 70-100\% menunjukkan bahwa senyawa obat tersebut dapat terabsorpsi dengan baik di dalam usus. Untuk Caco2, senyawa oleandrin diketahui memiliki nilai sebesar $25,490 \mathrm{~nm} /$ detik. Nilai tersebut berada pada rentang standar menengah (4-70\%) yang menandakan bahwa kedua senyawa tersebut memiliki kemampuan permeabilitas sedang terhadap sel Caco2 (PreADMET, 2021).

Pada aspek distribusi, dilakukan pengecekan terhadap nilai Plasma Protein Binding (PPB) dan Blood Brain Barrier Penetration (BBB). Senyawa oleandrin memiliki nilai PPB sebesar $82,203 \%$ yang menunjukkan bahwa oleandrin memiliki aktivitas ikatan yang lemah dalam protein plasma. Pada hasil simulasi BBB didapatkan nilai sebesar $0,046 \%$ yang menunjukkan bahwa senyawa tersebut memiliki kemampuan rendah untuk dapat berpenetrasi ke daerah sawar otak. Pada aspek metabolisme, diketahui bahwa senyawa oleandrin berperan sebagai inhibitor untuk CYP2C9 dan CYP3A4. Pada aspek toksisitas, dilakukan pengujian terhadap tikus dan mencit untuk mengetahui potensi mutagen dan karsinogen pada senyawa obat. Diketahui bahwa senyawa oleandrin tidak memiliki potensi mutagen tetapi memiliki potensi karsinogen (PreADMET, 2021). Meski begitu, senyawa ini masih dapat diteliti dan dikembangkan sebagai obat karena sudah terdapat penelitian secara in vitro yang membuktikan bahwa senyawa oleandrin memiliki kemampuan untuk menghambat proliferasi sel tumor, menstimulasi apoptosis sel tumor, dan secara efektif dapat mengurangi kadar sel induk penanda kanker.

Setelah dilakukan peninjauan dari aspek PreADMET selanjutnya dilakukan peninjauan dari aturan Lipinski. Kriteria obat yang akan diberikan secara oral perlu mengikuti aturan Lipinski's Rule of Five. Aturan ini membantu untuk melihat tingkat absorpsi atau permeabilitas suatu obat terhadap lipid 
Tabel 1: Hasil Simulasi Penambatan MolekUleR

\begin{tabular}{llllll}
\hline No. & Senyawa & Cluster & $\begin{array}{l}\text { Energi Ikat } \\
(\mathrm{kkal} / \mathrm{mol})\end{array}$ & $\mathrm{Ki}$ & $\begin{array}{l}\text { Interaksi dengan asam amino } \\
\text { (Ikatan Hidrogen Konvensional) }\end{array}$ \\
\hline 1 & Paclitaxel (obat pembanding) & 9 & $-7,38$ & $3,89 \mu \mathrm{M}$ & Val657 \\
2 & Oleandrin & 71 & $-7,22$ & $5,07 \mu \mathrm{M}$ & Tyr657; Arg609; \\
3 & Odorosida A & 5 & $-8,23$ & $0,92 \mu \mathrm{M}$ & Glu612; Ser613 \\
4 & Oleandrigenin & 75 & $-6,92$ & $8,42 \mu \mathrm{M}$ & Met660; Gln644 \\
\hline
\end{tabular}

Tabel 2: Hasil Simulasi Penambatan Molekuler

\begin{tabular}{|c|c|c|c|c|c|c|c|c|c|c|c|}
\hline \multirow{2}{*}{ No. } & \multirow{2}{*}{ Senyawa } & \multicolumn{2}{|c|}{ Absorpsi } & \multicolumn{2}{|c|}{ Distribusi } & \multicolumn{4}{|c|}{ Metabolisme } & \multicolumn{2}{|c|}{ Toksisitas } \\
\hline & & $\begin{array}{l}\text { HIA } \\
(\%)\end{array}$ & $\begin{array}{l}\mathrm{Caco} 2 \\
(\%)\end{array}$ & $\begin{array}{l}\text { PPB } \\
(\%)\end{array}$ & $\begin{array}{l}\mathrm{BBB} \\
(\%)\end{array}$ & $\begin{array}{l}\text { CYP } \\
2 \text { C19 }\end{array}$ & $\begin{array}{l}\text { CYP } \\
2 \text { C9 }\end{array}$ & $\begin{array}{l}\text { CYP } \\
\text { 2D6 }\end{array}$ & $\begin{array}{l}\text { CYP } \\
3 \mathrm{~A} 4\end{array}$ & Mutagen & Karsinogen \\
\hline 1 & $\begin{array}{l}\text { Paclitaxel } \\
\text { (obat pembanding) }\end{array}$ & 91,281 & 20,426 & 86,187 & 0,024 & Non & Inhibitor & Non & Inhibitor & $\begin{array}{l}\text { Non- } \\
\text { Mutagen }\end{array}$ & Negatif \\
\hline 2 & Oleandrin & 94,293 & 25,490 & 82,203 & 0,046 & Non & Inhibitor & Non & Inhibitor & $\begin{array}{l}\text { Non- } \\
\text { Mutagen }\end{array}$ & Positif \\
\hline
\end{tabular}
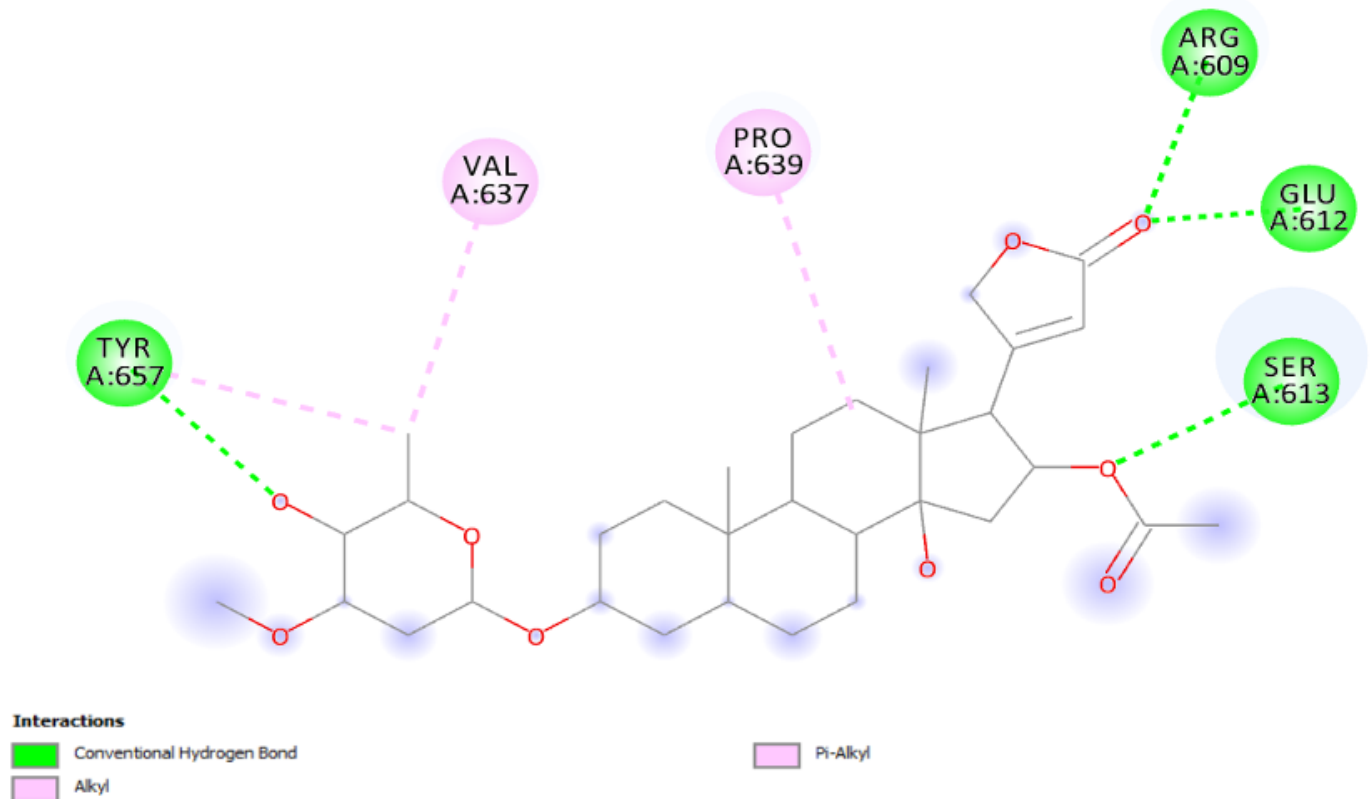

Gambar. 5: Interaksi kompleks oleandrin dan protein STAT-3

bilayer yang terdapat di tubuh manusia. Aturan Lipinski yaitu berat molekul $\leq 500$, nilai $\log \mathrm{P} \leq 5$, ikatan hidrogen donor $\leq 5$, dan ikatan hidrogen akseptor $\leq 10$ (Doak et al., 2014). Berdasarkan hasil aturan Lipinski (Tabel 3), oleandrin memenuhi kriteria sehingga penggunaan secara oral dapat dilakukan. Obat yang memiliki berat molekul lebih dari 500 g/mol akan memiliki permeabilitas yang kurang baik (Doak et al., 2014). Nilai log P berhubungan dengan polaritas dari senyawa. Semakin besar $\log$ P, maka semakin besar kelarutan senyawa tersebut dalam lemak atau dengan kata lain sifat lipofilisitasnya semakin besar (Utomo dkk., 2017). Nilai $\log \mathrm{P}$ yang negatif akan menyebabkan suatu molekul tidak dapat melewati membran lipid bilayer (Doak et al., 2014; Rukmono dkk., 2017). Salah satu syarat suatu senyawa dapat digunakan sebagai molekul obat yaitu tidak boleh terlalu hidrofobik karena akan lebih lama berada di lapisan lipid bilayer dan terdistribusi secara luas di dalam tubuh sehingga mengakibatkan selektivitas ikatan terhadap protein target menjadi berkurang. H-donor dan $\mathrm{H}$-akseptor merupakan besaran permeabilitas suatu obat untuk dapat melewati lapisan lipid bilayer dari sel (Setiawan et al., 2017).

\section{KESIMPULAN}

Dari simulasi penambatan molekuler yang telah dilakukan terhadap senyawa oleandrin, oleandrigenin, dan odorosida A dari tanaman Nerium oleander, diketahui bahwa senyawa oleandrin merupakan senyawa terbaik dibandingkan dengan senyawa lainnya. Hal ini dikarenakan oleandrin memiliki interaksi terbaik dengan STAT-3 yang ditunjukkan melalui nilai $\Delta \mathrm{G}$ dan $\mathrm{Ki}$ sebesar -7,22 kkal/mol dan 5,07 $\mu \mathrm{M}$ serta interaksi dengan residu Arg609 dan Ser613 sedangkan senyawa lainnya hanya memiliki satu atau bahkan tidak sama sekali interaksi dengan asam amino pada STAT-3. Hasil prediksi absorpsi, distribusi, metabolisme, dan toksisitas senyawa oleandrin juga menunjukkan hasil yang baik karena memiliki nilai HIA dan Caco2 sebesar 94,293\% dan 25,490 nm/detik. 
Kedua nilai tersebut menunjukkan bahwa oleandrin dapat terserap dengan baik di usus dan memiliki kemampuan untuk menembus membran. Nilai PPB dan BBB sebesar 82,203\% dan $0,046 \%$ menunjukkan profil distribusi oleandrin dan kemampuan menembus sawar darah otak. Dari segi toksisitas, ketiga senyawa tidak memiliki potensi mutagenik, namun sayangnya memiliki potensi karsinogenik. Meskipun oleandrin berpotensi karsinogenik, sudah terdapat penelitian secara in vitro yang membuktikan bahwa oleandrin memiliki kemampuan untuk menghambat proliferasi sel tumor, menstimulasi apoptosis sel tumor, dan secara efektif dapat mengurangi kadar sel induk penanda kanker. Selain itu, oleandrin dapat dikembangkan dalam bentuk sediaan oral karena sudah memenuhi kriteria aturan Lipinski.

\section{UCAPAN TERIMA KASIH}

Penulis mengucapkan terima kasih kepada semua pihak yang telah membantu dan mendukung penulis melakukan penelitian dan penulisan karya tulis ilmiah ini.

\section{Daftar Pustaka}

Arwansyah, A., Ambarsari, L., Sumaryada, T. I. 2014. Simulasi docking senyawa kurkumin dan analognya sebagai inhibitor reseptor androgen pada kanker prostat. Current Biochemistry. Vol. 1(1): 11-19

Ashariati, Ami. 2019. Manajemen Kanker Payudara Komprehensif. Surabaya: Universitas Airlangga Press

Darmawan, E., Melani, R., dan Raharjo, B. 2019. Gambaran Hubungan Regimen Dosis dan Efek Samping Kemoterapi pada Pasien Kanker di RSUD Prof. Dr. Margono Soekarjo Purwokerto Periode Bulan Januari-Februari Tahun 2019. Jurnal Majalah Farmasetika. Vol. 15(2): 113-122

Doak, B.C., Over, B., Giordanetto, F., and Kihlberg, J. 2014. Oral Druggable Space beyond the Rule of 5: Insights from Drugs and Clinical Candidates. Chemistry and Biology. Vol. 21(9): 1115-1142

Kanwal, N., Rasul, A., Hussain, G., Anwar, H., Shah, M.A., Sarfraz, I., Riaz, A., Batool, R., Shahbaz, M., Hussain, A., Selamoglu, Z. 2020. Oleandrin: A Bioactive Phytochemical and Potential Cancer Killer via Multiple Cellular Signaling Pathways. Food and Chemical Toxicology. Vol. 143

Ko, Y. S., Rugira, T., Jin, H., Park, S. W., and Kim, H. J. 2018. Oleandrin and Its Derivative odorosida A, Both Cardiac Glycosides, Exhibit Anticancer Effects by Inhibiting Invasion via Suppressing the STAT-3 Signaling Pathway. Int. J. Mol. Sci. Vol. 19(3350): 1-17

Kumar, A., De, T., Mishra, A., and Mishra, A. K. 2013. Oleandrin: A Cardiac Glycosides with Potent Cytotoxicity. Pharmacognosy Reviews. Vol. 7(14): 131-139

Laksmiani, N. P. L., N. L. P. V. Paramita, and I. M. A. G. Wirasuta. 2016. In Vitro and in silico Antioxidant Activity of Purified Fractions from Purple Sweet Potato Ethanolic Extract. International Journal of Pharmacy and Pharmaceutical Sciences. Vol. 8: 177-181

Lestari, T. 2015. Studi Interaksi Senyawa Turunan 1,3Dibenzoiltiourea sebagai Ribonukleotida Reduktase Inhibitor. Jurnal Farmasi Indonesia. Vol. 7: 163-169

Liu, L-J., Leung, K-H., Chan, DS-H., Wang, Y-T., Ma, D-L., and Leung, C-H. 2014. Identification of a Natural Product-Like STAT3 Dimerization Inhibitor by
Structure-Based Virtual Screening. Cell Death and Disease. Vol. 5(1293): 1-10

Liu, Zhe, Ge, Xianmin, Gu, Yuchen, Huang, Yingying, Liu, Hao, Yu, Meiling, Liu,Yamin. 2020. Small Molecule STAT3 Inhibitor, 6Br-6a Suppresses Breast Cancer Growth in vitro and in vivo. Biomedicine Pharmacotherapy. Vol. 121

Ma, Jia-hui, Qin, Li, dan Li, Xia. 2020. Role of STAT3 Signaling Pathway in Breast Cancer. BioMed Central. Vol. 18(33): 1-13

Mas'ula, Yonahar dan Kusuma, A.S.W. 2018. Artikel Tinjauan: Aktivitas Antikanker Tanaman Rumput Lidah Ular (Hedyotis difussa Willd.). Farmaka. Vol. 15(3): $17-23$

MIMS Indonesia. 2021. Paclitaxel. Indication, Dosage, Side Effect, Tersedia secara online di http://www.mims.com/indonesia/drug/info/paclitaxel/ (Diakses pada 28 Juni 2021)

Muttaqin, F.Z., Pratama, M.F., and Kurniawan, F. 2019. Molecular Docking and Molecular Dynamic Studies of Stilbene Derivative Compounds as Sirtuin-3 (SIRT3) Histone Deacetylase Inhibitor on Melanoma Skin Cancer and Their Toxicities Prediction. Journal of Pharmacopolium. Vol. 2(2): 112-121

Pusat Informasi Obat Nasional Badan Pengawas Obat dan Makanan. 2021. Paclitaxel. Tersedia secara online di http://pionas.pom.go.id/obat/paclitaxel (Diakses pada 28 Juni 2021)

PreADMET. 2021. ADME prediction. Tersedia secara online di https://preadmet.bmdrc.kr/adme-prediction/ (Diakses pada 27 Maret 2021) PreADMET. 2021. Toxicity prediction. Tersedia secara online di https://preadmet.bmdrc.kr/toxicity-prediction/ (Diakses pada 27 Maret 2021)

Rukmono, R., Fajriaty, I., Riza, H., dan Handani, M. 2017. Virtual Screening metabolit Aktif Senyawa Asam dari Pacar Air (Impatiens balsamina L.) terhadap Reseptor Sulfonilurea. Jurnal Mahasiswa Farmasi Fakultas Kedokteran dan Ilmu Kesehatan UNTAN. Vol. 4(1): 1-9

Setiawan, T., Ambarsari, L., and Sumaryada, T. 2017. Anticancer Study of Wonogiri's Curcuma Xanthorrhiza roxb Ethanol Fraction as Jamu by Flexible Docking Methods. International Journal of Hybrid Information Technology. Vol. 10(1): 277-288

Siegel, R. L., Miller, K. D., Fuchs, H. E., and Jemal, A. 2021. Cancer Statistics. Cancer Journal for Clinicians. Vol.73(1): 7-33

Sgrignani, J., Garofalo, M., Matkovic, M., Merulla, J., Catapano, C. V., and Cavalli, A. 2018. Structural Biology of STAT3 and Its Implications for Anticancer Therapies Development. Int. J. Mol. Sci. Vol. 19(1591): 1-15

Sukandar, E.Y., Hartini, S., dan Rizkita, P. 2014. Evaluasi Reaksi Obat Merugikan pada Pasien Kemoterapi Kanker Payudara di Salah Satu Rumah Sakit di Bandung. Jurnal Ilmu Kefarmasian Indonesia. Vol. 12(2): 183-192

Utomo, S.B., Sanubari,F., Utami B., dan Nurhayati, N.D. 2017. Analisis Hubungan Kuantitatif Struktur dan Aktivitas Analgesik Senyawa Turunan Meperidin Menggunakan Metode Semiempiris AM1. Jurnal Kimia dan Pendidikan Kimia. Vol. 2(3): 158-168 
Walker, S. R., Chaudhury, M., Frank, D. A. 2011. STAT3 Inhibition by Microtubule-Targeted Drugs: Dual Molecular Effects of Chemotherapeutic Agents. Molecular and Cellular Pharmacology. Vol. 3(1): 13-19

Wongkar, F. J., Wuyung, P. E., Stephanie, M. 2019. Aspek Klinik, Molekuler, dan Histopatologik Adenoma Hepatoseluler. Pratista Patologi. Vol. 6(1): 6-16 